\title{
Circadian Rhythms: Biological Clock of Living Organisms
}

\section{Md. Sahab Uddin* and Abdullah AI Mamun}

Department of Pharmacy, Southeast University, Dhaka, Bangladesh

\section{Editorial}

The biological operation of living beings that spectacle an endogenous, entrainable oscillation of roughly $24 \mathrm{~h}$ is called circadian rhythm [1]. The term circadian is derived from the Latin words circa represent "around" and dies represent "day". Even though, circadian rhythm is internally engendered they can be moderated by external gestures, for example, temperature and sunlight [2].

The suprachiasmatic nucleus (SCN) is called the biological clock of mammals [3]. SCN is located in a tiny cluster of hypothalamic nerve cells that encloses about 20,000 neurons. The foremost function of the SCN is to act as a cardinal circadian pacemaker so as to control the sleep (i.e., rest) and wake (i.e., activity) cycle. The sleep and wake befall in approximately $24 \mathrm{~h}$ cycle that grew in consequence of the amendment of solar cycle [4]. The SCN gets info about illumination through the eyes. When light enters into the eye it causes triggering of retina neurons that transform light (i.e., photons) to electrical signals. The retina of the eye comprises two genres of photoreceptors called rods and cones accountable for scotopic vision $[5,6]$.

The retina also contains particular photosensitive ganglion cells that succor in synchronization of the cardinal circadian clock [7]. A subset of retinal ganglion cells serves as the precursor for the retinohypothalamic tract (i.e., linked in the circadian rhythms of mammals) leading to the SCN [8]. If cells from the SCN are removed and cultured can engender autonomous circadian vacillations of clock gene expression as well as neuronal firing [9]. Studies suggested that each SCN cell acts as a functional clock, typically harmonized with the action of its contiguous cells. In fact, deprived of external time clues, human bodies conserve a sleep-wake rhythm of almost $24 \mathrm{~h} \mathrm{[10].} \mathrm{Scheer} \mathrm{et} \mathrm{al.} \mathrm{reported} \mathrm{that}$ human subjects can at least be entrained to a $23.5 \mathrm{~h}$ day length and a $24.65 \mathrm{~h}$ Martian sol [11]. In Figure 1, few sorts of the circadian biological clock of the human being represented.

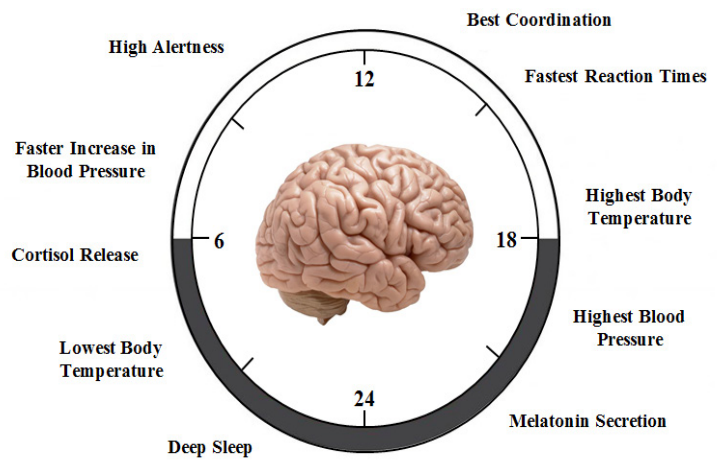

Figure 1: Few landscapes of the human circadian (i.e., $24 \mathrm{~h}$ ) biological clock. The alterations of the light owing to the day/ night cycle are straightly sensed by the eyes. The info of the light is transported to the suprachiasmatic nucleus to engender circadian rhythmicity. This engendered circadian rhythmicity is transformed into output tracks to control the behavior, physiology and metabolism of the organisms.
However, the mechanism of the circadian biological clock endured an enigmatic for many years. In the 1970's, Seymour Benzer et al. decided to discover genes that are liable for circadian rhythm in fruit flies [12]. They reported that mutations in an anonymous gene are causative for the interference of the circadian clock of flies. They entitled this gene period (per).

But, how the clock really operates is a big query. In 1984, Jeffrey $\mathrm{CH}$ et al. succeeded in isolating the per gene $[13,14]$. The study of Jeffrey $\mathrm{CH}$ and Michael $\mathrm{R}$ were able to discover that PER protein that encoded by per gene, accrued in the course of the night and degraded in the course of the day [13]. Consequently, PER protein levels vacillate over a $24 \mathrm{~h}$ cycle, in synchrony with the circadian rhythm.

After that, the researchers decided to find in what manner such sort of circadian oscillations could be engendered and sustained. It may in consequence of impeding of per by PER conjectured by Jeffrey $\mathrm{CH}$ and Michael R [15]. Later the researchers reasoned that PER could avert its creation and thus control its level in an incessant, cyclic rhythm by a negative feedback loop.

PER protein is a cytoplasmic protein, so how this protein entered in the cell nucleus? The subsequent study of Jeffrey $\mathrm{CH}$ and Michael R suggested that PER is formed in the nucleus at night [16]. Then another fact is how did it become here? In 1994, Michael W discovered another gene, timeless (tim) that encoded the protein, TIM [17]. This TIM is also prerequisite for typical circadian rhythm. Later he exposed that TIM and PER, both proteins were capable to arrive in the nucleus to impede per gene action to close the inhibitory feedback loop.

Aforesaid controlling feedback mechanism clarified how this vacillation of the levels of cellular protein appeared. Then queries lingered what regulated the frequency of the vacillations? Michael WY revealed another gene, double-time (dbt) that encoded DBT protein that delayed the accrual of the PER [18]. This proved how a vacillation is accustomed to more strictly stalemate a $24 \mathrm{~h}$ cycle.

Numerous studies identified and characterized the function of several clock genes. In mammals, circadian rhythm comprises of a network of genes with numerous positive and negative feedback loops [19]. The family of bHLH-PAS-containing transcription factors, CLOCK and BMAL1 are accountable to exert positive feedback loops. Firstly CLOCK and BMAL1 bind to each other to form a heterodimer

*Corresponding author: Md. Sahab Uddin, Department of Pharmacy, Southeast University, Dhaka, Bangladesh, Tel: +880 1710220110; E-mail: msu_ neuropharma@hotmail.com, msu-neuropharma@hotmail.com

Received: October 05, 2017; Accepted November 08, 2017; Published November 15, 2017

Citation: Uddin MS, Al Mamun A (2017) Circadian Rhythms: Biological Clock of Living Organisms. Biol Med (Aligarh) 10: e129. doi: 10.4172/0974-8369.1000e129

Copyright: $\odot 2017$ Uddin MS, et al. This is an open-access article distributed under the terms of the Creative Commons Attribution License, which permits unrestricted use, distribution, and reproduction in any medium, provided the original author and source are credited. 
Citation: Uddin MS, Al Mamun A (2017) Circadian Rhythms: Biological Clock of Living Organisms. Biol Med (Aligarh) 10: e129. doi: 10.4172/09748369.1000e129

that binds with Periods (i.e., Per1, Per2 and Per3) and Cryptochromes (i.e., Cry1 and Cry2) genes [20]. In case of negative feedback loop, PERs and CRYs bind with each other to form heterocomplexes. These generated heterocomplexes translocate back to the nucleus to block the transcription [21].

Except for aforementioned crucial feedback loops, orphan nuclear receptors REV-ERBa and RORa also serve as a regulatory feedback loop. This feedback loop is also controlled by the heterodimer (i.e., CLOCK/BMAL1) of the positive feedback loop [21]. Furthermore, numerous post-translational modifications are also linked to the typical functioning of the circadian rhythm [20]. In fact, a few hours would be ample for a molecular feedback loop to operate a cycle by only transcriptional triggering and subsequent feedback repression [20].

The biological clock is linked in numerous features of the multifarious physiology with insinuations for our health and wellbeing. The discoveries of the molecular mechanisms controlling the circadian rhythm led to the award of the 2017 Nobel Prize in Physiology or Medicine jointly to Jeffrey C Hall, Michael Rosbash and Michael W Young.

\section{Acknowledgements}

The authors wish to thank the anonymous reviewer(s)/editor(s) of this article for their constructive reviews.

\section{Competing Interests}

The authors state no competing interests.

\section{References}

1. Baker FC, Driver HS (2007) Circadian rhythms, sleep, and the menstrual cycle Sleep Med 8: 613-22.

2. No Authors Listed (2017) Circadian Rhythm

3. Reghunandanan V, Reghunandanan R (2006) Neurotransmitters of the suprachiasmatic nuclei. J Circadi Rhyth 4: 2 .

4. Moore RY (2007) Suprachiasmatic nucleus in sleep-wake regulation. Sleep Med 8: 27-33.

5. Guyton AC, Hall, JE (2006) Textbook of medical physiology. Elsevier Saunders, China.
6. Amran MS, Uddin MS (2014) Pharmakon comprehensive pharmaceutical pharmacology (1stedn). Krishnachura Prokashoni, Dhaka.

7. Do MT, Yau KW (2010) Intrinsically photosensitive retinal ganglion cells Physiolog Revie 90: 1547-1581.

8. Gooley JJ, Lu J, Chou TC, Scammell TE, Saper CB (2001) Melanopsin in cells of origin of the retinohypothalamic tract. Nat Neurosci 4: 1165.

9. Welsh DK, Takahashi JS, Kay SA (2010) Suprachiasmatic nucleus: Cell autonomy and network properties. Ann Rev Physio 72: 551-77.

10. No Authors Listed (2017) The human suprachiasmatic nucleus.

11. Scheer FA, Wright Jr KP, Kronauer RE, Czeisler CA (2007) Plasticity of the intrinsic period of the human circadian timing system. PloS one 2: e721.

12. Takahashi JS, Shimomura K, Kumar V (2008) Searching for genes underlying behavior: Lessons from circadian rhythms. Science 322: 909-912.

13. Zehring WA, Wheeler DA, Reddy P, Konopka RJ, Kyriacou CP, et al. (1984 P-element transformation with period locus DNA restores rhythmicity to mutant, arrhythmic Drosophila melanogaster. Cell 39: 369-76.

14. Bargiello TA, Jackson FR, Young MW (1984) Restoration of circadian behavioural rhythms by gene transfer in Drosophila. Nature 312: 752-754

15. Hardin PE, Hall JC, Rosbash M (1990) Feedback of the Drosophila period gene product on circadian cycling of its messenger RNA levels. Nature 343: 536-40.

16. Siwicki KK, Eastman C, Petersen G, Rosbash M, Hall JC (1988) Antibodies to the period gene product of Drosophila reveal diverse tissue distribution and rhythmic changes in the visual system. Neuron 1: 141-50.

17. Vosshall LB, Price JL, Sehgal A, Saez L, Young MW (1994) Block in nuclea localization of period protein by a second clock mutation, timeless. Science 263: 1606-10.

18. Price JL, Blau J, Rothenfluh A, Abodeely M, Kloss B, et al. (1998) Double-time is a novel Drosophila clock gene that regulates PERIOD protein accumulation. Cell 94: 83-95.

19. Pett JP, Korencic A, Wesener F, Kramer A, Herzel H (2016) Feedback loops of the mammalian circadian clock constitute repressilator. PLoS Comput Bio 12: e1005266.

20. Kwon I, Choe HK Son GH, Kim K (2011) Mammalian molecular clocks. Experimen Neurobio 20: 18-28.

21. Gallego M, Virshup DM (2007) Post-translational modifications regulate the ticking of the circadian clock. Nat Rev Mol Cell Biol 8: 139-148. 